\title{
The Elusive Target of Congestive Heart Failure Treatment: delaying the Inevitable
}

\author{
Awad Magbri*, Eussera El-Magbri, Mariam El-Magbri, Shaukat Rashid and Balhinder Brar \\ Toledo Vascular Access Center, Toledo, USA
}

Submission: June 21, 2018; Published: August 22, 2018

*Corresponding author: Awad Magbri, Dialysis Access Center of Pittsburgh, Toledo Vascular Access Center, Toledo, OH, Pennsylvania, USA, Email: elmagbri@hotmail.com

\begin{abstract}
Keywords: Congestive heart failure; Left ventricular ejection fraction; Heart failure with preserved ejection fraction; Heart failure with reduced ejection fraction; LV mass; End-diastolic volume; Pulmonary capillary wedge pressure; Brain natriuretic peptide; N-terminal pro-BNP; Left ventricular assisted device (LVAD)

Abbreviations: LVAD: Left Ventricular Assisted Device; CVVHDF: Continuous Veno-Venous Hemodiafiltration; SNS: Sympathetic Nervous System; RAAS: Renin-Angiotensin-Aldosterone System; ADH: Antidiuretic Hormone; SBP: Systolic Blood Pressure; WRF: Worsening Renal Failure; CT: Computed Tomography; MRI: Magnetic Resonance; TTE: Trans-Thoracic Echocardiography; BNP: Brain Natriuretic Peptide; NPV: Negative Predictive Value; ACEI: Angiotensin-converting enzyme inhibitors; ARBs: Angiotensin Receptor Blockers; ICD: Intra-Cardiac Defibrillators; CRT: Chronic Resynchronization Therapy
\end{abstract}

\section{Case History}

The patient is 72-year-old Caucasian male with history of type-2 diabetes mellitus, coronary artery disease with drug eluting stent, and congestive heart failure with ejection fracture of $40 \%$ was admitted to hospital with shortness of breath at rest. The patient noticed swelling of the legs for 4 weeks despite salt restriction and diuretics. His medications include Humalog (75/25) 20 units QD, frusemide 40 mg BID, metolazone $2.5 \mathrm{mg}$ QD, spironolactone $12.5 \mathrm{mg}$ QD, carvedilol $12.5 \mathrm{mg}$ BID, Ramipril 10 $\mathrm{mg} \mathrm{QD}$, atorvastatin $40 \mathrm{mg} \mathrm{QD}$, clopidogrel $75 \mathrm{mg} \mathrm{QD}$, and aspirin $81 \mathrm{mg}$ QD. His blood pressure was 100/60 mmHg, pulse 102 beats/ min, The patient had marked jugular venous distention, crackles at the lung bases, an S3 gallop, positive hepato-jugular reflux, and pitting edema up to the knees. His laboratory investigation showed sodium of $134 \mathrm{mEq} / \mathrm{L}$, potassium of $3.8 \mathrm{mEq} / \mathrm{L}$, chloride $90 \mathrm{mEq} / \mathrm{L}$, bicarbonate $28 \mathrm{mEq} / \mathrm{L}$, blood urea nitrogen $46 \mathrm{mg} / \mathrm{L}$, creatinine $1.8 \mathrm{mg} / \mathrm{L}$, with an estimated GFR of $<60 \mathrm{~mL} /$ minute, and glucose of $100 \mathrm{mg} / \mathrm{L}$. His HgbA1C was 7\%. His urinalysis was significant for 2+ proteinuria. EKG showed tachycardia with nonspecific St and T wave changes, His weight was $98 \mathrm{~kg}$.

The patient was treated for volume overload to relief his congestive symptoms with intra-venous frusemide at $5 \mathrm{mg} / \mathrm{h}$, continuous infusion, after a waiting period of 6 hours a neseritide was added at $0.01 \mathrm{ug} / \mathrm{kg} / \mathrm{min}$. As a result, his dyspnea had clinically improved with the nesiritide and his frusemide infusion was decreased to keep his SBP 90-100 mmHg. However, his urine output was not adequately increased and the treating cardiologist started him on nitro-glycerin at $20 \mathrm{ug} / \mathrm{min}$. The patient could not tolerate the medication because of low blood pressure $(<90 \mathrm{mmHg}$ systolic) and the nitroglycerine had to be discontinued.

Even though the patient was subjectively improved, nevertheless, his urine output and edema did not improve substantially. His weight decreased from $98 \mathrm{~kg}$ to $96 \mathrm{~kg}$. His creatinine on the other hand increased to $2.1 \mathrm{mg} / \mathrm{L}$ and his SBP was ranging from $90-100 \mathrm{mmHg}$. A decision was made to start him on dobutamine in view of his low EF, to improve his cardiac output by decreasing the afterload and increasing inotropy.

Despite dobutamine, his urine output did not materialize significantly in 24 hours. Milrinone was added to improve an inotropy with a bolus of $25 \mathrm{ug} / \mathrm{kg}$ followed by $0.1 \mathrm{ug} / \mathrm{kg} / \mathrm{min}$. Despite this change in his regimen of treatment his edema, urine output, and BP did not significantly improve. His BP was 90/70 $\mathrm{mmHg}$ and his serum creatinine had gone up to $3.2 \mathrm{mg} / \mathrm{L}$.

The patient developed type-2 cardio-renal syndrome and his diuretics, nesiritide, and nitroglycerine were stopped, and he was started on renal replacement therapy in the form of Continuous Veno-Venous Hemodiafiltration (CVVHDF) to improve both fluid overload and worsening renal function.

\section{Case Discussion}

Clinically, heart failure is classified into two major types based on the functional status of the heart: heart failure with preserved 
ejection fraction (HFpEF) and heart failure with reduced ejection fraction (HFrEF). Heart failure with preserved ejection fracture is common in females and older adults. Ejection fraction is usually $>50 \%$ and the volume of the left-ventricular cavity is typically normal. At the same time, the left ventricular wall is thickened and stiff and the ratio of the LV mass/end-diastolic volume is high [1]. Based on the EF the HFpEF is categorized as borderline if the $\mathrm{EF}$ is between $41 \%$ and $49 \%$, and improved $\mathrm{HF}$ if the $\mathrm{EF}$ is $>40 \%$ [2]. HFpEF has not been shown to respond to standard pharmacological treatment as compared to HFrEF, and therefore, carry a poor prognosis especially during the decompensated phase of HF $[1,3,4]$.

In HFrEF, the LV cavity is typically dilated, and the ratio of the LV mass/end-diastolic volume is either normal or reduced. Heart failure with reduced ejection fracture responds favorably to pharmacological treatment and demonstrated better prognosis at the beginning. Heart failure can be grouped into 4 groups based on the pulmonary capillary wedge pressure and cardiac index, (Table 1).

Table 1: (subgroups of $\mathrm{HF}$ )

\section{- $\quad$ PCWP $18 \mathrm{mmHg}$}

- $\quad$ Cardiac Index (2.1 L/min/M2).

\begin{tabular}{|c|c|}
\hline Group A & Group B \\
\hline Group C & Group D \\
\hline
\end{tabular}

In heart failure there is ineffective blood volume and pressure, which stimulate the Sympathetic Nervous System (SNS), and Renin-Angiotensin-Aldosterone System (RAAS), causing the release of Antidiuretic Hormone (ADH), which all together lead to ventricular enlargement, negative ventricular remodeling and symptoms of heart failure.

In sub-group A of heart failure, the patient is presented with good cardiac index $(>2.1 \mathrm{~L} / \mathrm{min} / \mathrm{M} 2)$ and the PCWP is $<18 \mathrm{mmHg}$. These patients' responds well to diuretics and their chest x-ray would not show evidence of congestion. The prognosis in these patient is good. In sub-group B the cardiac index is still $>2.1 \mathrm{~L} /$ min/M2, but the PCWP is $>18 \mathrm{mmHg}$ and therefore, this group showed signs of lung congestion on chest $x$-ray. These patients also respond well to diuretics and vaso-dilators.In sub-groups $\mathrm{C}$ and $\mathrm{D}$ the cardiac index is low with low Systolic Blood Pressure (SBP) usually $<110 \mathrm{mmHg}$. The difference between these 2 subgroups is that in sub-group $\mathrm{C}$ the PCWP is $<18 \mathrm{mmHg}$ in contrast to sub-D where the PCWP is $>18 \mathrm{mmHg}$. In sub-group $\mathrm{C}$ the patient is dry with low cardiac output and low cardiac index, while patients in sub-group D, they are wet since their PCWP is $>18 \mathrm{mmHg}$ but with low cardiac output and low cardiac index.

Patients in category C and D may present with ischemic or congestive nephropathy with Worsening Renal Failure (WRF). The prognosis in these 2 sub-groups are guarded and short of cardiac transplant there is no definitive treatment for these patients. Table
2 showed the sensitivity and specificity of the different symptoms and signs of heart failure [5,6].

Table2: symptoms and signs of HF with its corresponding sensitivity and specificity $[5,6]$.

\begin{tabular}{|c|c|c|}
\hline Symptoms \&Signs of HF & Sensitivity & Specificity \\
\hline SOB/dyspnea & $84-100 \%$ & $17-34 \%$ \\
\hline Orthopnea & $22-50 \%$ & $74-77 \%$ \\
\hline $\begin{array}{c}\text { Fatigue/weakness/lethargy, abdominal } \\
\text { distention, Rt hypochondrial pain }\end{array}$ & $23 \%$ & $80 \%$ \\
\hline Tachycardia & $7 \%$ & $99 \%$ \\
\hline Pedal edema & $39 \%$ & $92 \%$ \\
\hline Crackles & $60 \%$ & $78 \%$ \\
\hline S3 gallop & $13 \%$ & $99 \%$ \\
\hline Hepato-jugular reflux & $24 \%$ & $96 \%$ \\
\hline Ascites & $1 \%$ & $97 \%$ \\
\hline BNP & $70 \%$ & $99 \%$ \\
\hline N-terminal pro-BNP & $99 \%$ & $85 \%$ \\
\hline
\end{tabular}

The diagnosis of HF includes history and physical findings, chest X-ray to assess cardiac size and congestions of the lungs, Computed Tomography (CT) and Magnetic Resonance MRI) of the heart to assess the LV volume and EF measurements. The additional information that can be obtained from MRI are the myocardial perfusion, viability and fibrosis. MRI also provides high anatomical resolution of all aspects of the heart and surrounding structures. Trans-Thoracic Echocardiography (TTE) is a valuable tool to assess ventricular function, size, wall thickness, wall motion and valve function. It is also helpful to evaluate the ejection fraction of the Left Ventricle (LVEF). The TTE is also valuable in assessing the mitral valve inflow pattern, the pulmonary venous inflow pattern, mitral annular velocity, to precisely evaluate LV filling and the left atrial pressure of the dysfunctional heart. Other parameters that are usually measured with TTE are tricuspid valve regurgitant gradient, measurement of IVC diameters and its variation with respiration which can provide estimate of pulmonary artery pressure and central venous pressure [7]. Many of these parameters are used for therapeutic and prognostic purposes $[8,9]$. Cardiac catheterization and coronary angiography are sometimes necessary in patients with new onset heart failure and angina symptoms [8].

Brain NatriureticPeptide (BNP) and N-terminal pro-BNP (NT-pro-BNP) have high sensitivity and specificity Table1. They are recommended for outpatient and inpatient setting for the diagnosis and prognosis of HF [2]. BNP levels of $\leq 100 \mathrm{pg} / \mathrm{mL}$ have $90 \%$ Negative Predictive Value (NPV), and a value of $\geq 500 \mathrm{pg} /$ $\mathrm{mL}$ have an $81 \%$ Positive Predictive Value (PPV) for the diagnosis of HF [10]. The level of BNP is also a strong predictor of risk of death and cardiovascular events in patients diagnosed with HF. It is to be noted nonetheless high levels of BNP is seen in renal failure, pulmonary embolism, pulmonary hypertension and 
chronic hypoxia. Lower levels of BNP have been seen in obese and overweight patients.

Additionally, there is no difference in BNP and NT-pro-BNP as far as diagnosis and prognosis are concerned except that NTpro-BNP are less affected by obesity [8,11]. BNP of $<100 \mathrm{pg} /$ $\mathrm{mL}$ or NT-pro-BNP $<300 \mathrm{pg} / \mathrm{mL}$ rules out the diagnosis of $\mathrm{HF}$, while $B N P \geq 500 \mathrm{pg} / \mathrm{mL}$ or NT-pro-BNP $\geq 1800 \mathrm{pg} / \mathrm{mL}$ rules in HF. Both BNP and NT-pro-BNP levels aid in the decisions regarding admission/discharge and risk stratification for HF patients in the emergency department.

Patients with $\mathrm{BNP}<200$ at admission have a mortality rate of $2 \%$ as opposed to $9 \%$ in mortality rate seen in patients with BNP $>200 \mathrm{pg} / \mathrm{mL}$. NT-pro-BNP levels $\geq 5000 \mathrm{pg} / \mathrm{mL}$ at admission have been associated with in-hospital mortality rate of $22.5 \%$ and longer length of stay in the remaining surviving patients [12].

The predictors of poor outcome and high mortality rate in heart failure;

a. High age group

b. High BUN and creatinine (15 mmol/2.72 mg/dl respectively)

c. High heart rate and low SBP (HR>100bpm, SBP 115 $\mathrm{mmHg}$, respectively)

d. Low serum sodium levels

e. Dyspnea at rest

f. Lack of long-term use of Beta blockers

g. Male gender

h. Lower BMI

i. $\quad$ NT-pro-BNP $\geq 986 \mathrm{pg} / \mathrm{mL}$

j. $\quad$ LVEF $<45 \%$

k. S3 gallop

l. Increased pulmonary artery wedge pressure

m. DM

n. Raised catecholamine and BNP levels.

The major goals of heart failure treatment is not to cure the disease but to [13];

1. Improve prognosis and reduce mortality

2. Alleviate symptoms and reduce morbidity

3. Reduce the length of hospital stay and subsequent readmission.

4. Prevent target organ damage

5. Appropriately manage the co-morbidities that may contribute to poor prognosis.
That can be accomplished by using the pharmacological and non-pharmacological therapy. The pharmacological therapy consists;

a. Using oxygen to keep oxygen saturation $>90 \%$ and $\mathrm{PaO} 2>60 \%$.

b. Using diuretics including loop diuretics, thiazide and potassium sparing to reduce edema by the reduction of blood volume and venous pressure,

c. Angiotensin-converting enzyme inhibitors (ACEI), or angiotensin receptor blockers (ARBs),

d. Beta-blockers for neuro-humoral modification along with survival benefits and prevention of arrhythmia.

e. Aldosterone antagonists,

f. digoxin,

g. anticoagulants and

h. Inotropic agents to restore organ perfusion and reduce congestion in patients with HFrEF.

i. The non-pharmacological therapy comprises of

j. The use of Intra-Cardiac Defibrillators (ICD), with or without Chronic Resynchronization Therapy (CRT) to maintain the optimal cardiac output [14].

k. The utilization of renal replacement therapy (CVVH, CVVHD, CVVHDF) for fluid overload,

l. Left Ventricular Assisted Devise (LVAD) as a bridge for heart transplant or permanent mechanical assistance (destination therapy) in selected patients who are not eligible for cardiac transplantation.

m. Back to our patient who has many poor predictors of outcome with high mortality risk, these are;

n. Age and male gender

o. Presence of DM and CAD

p. High BUN and creatinine

q. Low SBP with low EF

r. The presence of S3 gallop

s. Low serum sodium

Despite the many efforts and expensive treatments that the patient received he eventually succumbed to his disease after 3 months. One wonder why we tossed expensive and unclear procedures if we know the odds are stacking against us. In this time of limited resources, one should be realistic and accept the facts that eventually you cannot prevent the inevitable but you can only delay it. By delaying the inevitable, you know that you're indulging in too expensive, very taxing, and futile practice that may have a permanent negative impact on the health system. An 
alternative solution is addressing the end of life concerns and hospice issues that would be in the best interest of every-body involved.

\section{References}

1. Ohtani T, Mohammed SF, Yamamoto K, Dunlay SM, Weston SA, et al. (2012) Diastolic stiffness as assessed by diastolic wall strain is associated with adverse remodeling and poor outcomes in heart failure with preserved ejection fraction. Eur Heart J 33(14): 1742-1749.

2. Dassanayaka S, Jones SP (2015) Recent developments in heart failure. Circ Res 117: e58-e63.

3. Zamani P, Rawat D, Shiva-Kumar P, Geraci S, Bhuva R, et al. (2015) Effect of inorganic nitrate on exercise capacity in heart failure with preserved ejection fraction. Circulation 131(4): 371-380.

4. Glean AA, Ferguson SK, Holdsworth CT, Colburn TD, Wright JL, et al. (2015) Effect of nitrite infusion on skeletal muscle vascular control during exercise in rats with chronic heart failure. Am J Physiol Heart Circ Physiol 309(8): H1354-H1360.

5. Lindenfeld J, Albert NM, Boehmer JP, Collins SP, Ezekowitz JA, et al (2010) HFSA 2010 Comperhensive Heart Failure Practice Guideline. J Card Fail 16(6): e1-e194.

6. Marti CN, Georgiopoulou VV, Kalogeropoulos AP (2013) Acute heart failure: Patient characteristics and pathophysiology. Curr Heart Fail Rep 10(4): 427-433.

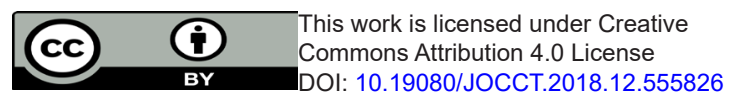

7. Paterson I, Mielniczuk LM, O’Meara E, So A, White JA (2013) Imaging heart failure: current and future applications. Can J Cardiol 29(3): 317328.

8. Yancy CW, Jessup M, Bozkurt B, Butler J, Casey DE Jr, et al. (2013) ACCF/AHA guideline for the management of heart failure: A report of the American College of Cardiology Foundation/American Heart Association Task Force on Practice Guideline. J Am Coll Cardiol 62(16): e147-e239.

9. Morbach C, Lin BA, Surgeng L (2014) Clinical application of threedimensional echocardiography. Prog Cardiovasc Dis 57(1): 19-31.

10. Maries L, Manitiu I (2013) Diagnostic and prognostic values of B-type natriuretic peptide (BNP) and $\mathrm{N}$-terminal fragment brain natriuretic peptide (NT-pro-BNP). Cardiovasc J Afr 24(7): 286-289.

11. Pfister R, Scholz M, Wielckens K, Erdmann E, Schneider CA (2004) Use of NT-pro-BNP in routine testing and comparison to BNP. Eur J Heart Fail 6(3): 289-293.

12. Murtagh G, Canniffe C, Mahgoub M, Blake L, McCarroll N, et al. (2009) Introduction of an NT-pro-BNP assay to an acute admission unit- A 2-year audit. Eur J Intern Med 20(1): 58-62.

13. Tamargo J, Lopez-Sendon J (2011) Novel therapeutic targets for the treatment of heart failure. Nat Rev Drug Discov 10(7): 536-555.

14. Moss AJ, Hall WJ, Cannom DS, Klein H, Brown MW, et al. (2008) Cardioresynchronization therapy for the prevention of heart-failure events. $\mathrm{N}$ Engl J Med 361(14): 1329-1338.

\begin{tabular}{|l|}
\hline \multicolumn{1}{|c|}{ Your next submission with Juniper Publishers } \\
will reach you the below assets \\
- Quality Editorial service \\
- Swift Peer Review \\
- Reprints availability \\
- E-prints Service \\
- Manuscript Podcast for convenient understanding \\
- Global attainment for your research \\
- Manuscript accessibility in different formats \\
( Pdf, E-pub, Full Text, Audio) \\
- Unceasing customer service \\
Track the below URL for one-step submission \\
https://juniperpublishers.com/online-submission.php \\
\hline
\end{tabular}

